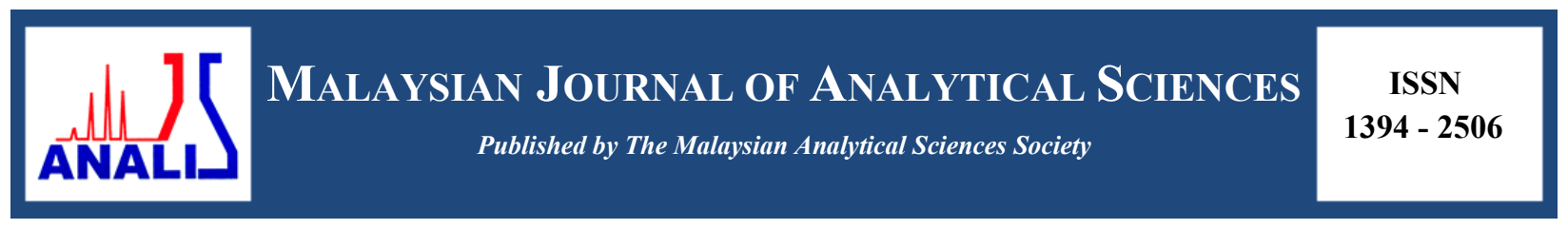

\title{
PRODUCTION OF BIOGAS THROUGH ANAEROBIC DIGESTION OF Cabomba furcata IN DIGESTER BATCH SYSTEM
}

\section{(Penghasilan Biogas Melalui Pencernaan Anaerobik daripada Cabomba furcata di dalam Sistem Penghadam Kelompok)}

\author{
Siti Afifah Muda ${ }^{1,3 *}$, Omar Syah Jehan Elham ${ }^{2,3}$, Hassimi Abu Hasan ${ }^{3}$, Siti Rozaimah Sheikh Abdullah ${ }^{3}$ \\ ${ }^{1}$ Section of Process, Chemical Engineering Technology, \\ Universiti Kuala Lumpur-Malaysian Institute of Chemical \& Bioengineering Technology (UniKL-MICET), \\ Lot 1988 Bandar Vendor Taboh Naning, 78000 Alor Gajah, Melaka, Malaysia \\ ${ }^{2}$ Faculty of Chemical Engineering, \\ Universiti Teknologi MARA, Cawangan Johor, Kampus Pasir Gudang, 81750 Masai, Johor, Malaysia \\ ${ }^{3}$ Department of Chemical and Process Engineering, Faculty of Engineering and Built Environment, \\ Universiti Kebangsaan Malaysia, 43600 UKM Bangi, Selangor, Malaysia \\ *Corresponding author: sitiafifahm@unikl.edu.my
}

Received: 21 October 2015; Accepted: 14 June 2016

\begin{abstract}
Biogas is produced from decomposition of organic waste such as sewage sludge, animal manure, and municipality solid wastes by microorganisms in anaerobic conditions. Biogas, which consist mainly of methane is a renewable energy source. It can be used for heating, power generation or upgrading to natural gas quality. In this study, the anaerobic treatability and biogas generation potential of Cabomba furcata (C. furcata) were examined in batch digesters. C. furcata collected from Chini Lake, Pahang was utilized as a substrate in biogas production. Slurry samples of $C$. furcata were prepared in 2 different mixture i.e., C. furcata/water ratio $(1: 1,1: 2$ and 1:3) and $C$. furcata/inoculums ratio $(1: 1,1: 2$ and 1:3). Throughout the experiment, the $\mathrm{pH}$ range was 5.5 to 7.0 while temperature range was 25 to $30{ }^{\circ} \mathrm{C}$ to enable anaerobic digestion in mesophilic condition for a retention time of 28 days. The results showed that the maximum methane production achieved at ratio of 1:3 for both mixture C. furcata/water and C. furcata/inoculums with production percentages up to 1.1 and $11.9 \%$, respectively. Moreover, the result indicated that the production of methane increased as the retention time increased. Therefore, native plant of $C$. furcata is a great potential as a substrate in the production of biogas for future renewable energy.
\end{abstract}

Keywords: Cabomba furcata, methane production, anaerobic digestion, renewable energy

\section{Abstrak}

Biogas terhasil daripada penguraian sisa organik seperti kumbuhan enapcemar, baja haiwan dan sisa pepejal perbandaran oleh mikroorganisma dalam keadaan anaerobik. Biogas terdiri daripada metana sebagai sumber tenaga yang boleh diperbaharui. Ia boleh digunakan untuk pemanasan, penjanaan kuasa atau peningkatan kepada kualiti gas asli. Melalui kajian ini, kebolehrawatan anaerobik dan kebolehan penjanaan biogas oleh Cabomba furcata (C. furcata) telah diperiksa di dalam penghadam kelompok. C. furcata telah dikumpul dari Tasik Chini, Pahang dan digunakan sebagai substrat dalam penghasilan biogas. Sampel cair $C$. furcata disediakan dengan 2 campuran yang berlainan i.e., nisbah $C$. furcata/air $(1: 1,1: 2$ dan 1:3) dan nisbah C. furcata/inokulum (1:1, 1:2 dan 1:3). Sepanjang kajian dijalankan, nilai pH adalah 5.5 hingga 7.0 manakala julat suhu ialah $25-30{ }^{\circ} \mathrm{C}$ menjadikan keadaan operasi penghadaman anaerobik sebagai mesofilik dan masa tahanan selama 28 hari. Keputusan kajian menunjukkan penghasilan biogas yang maksimum berlaku pada nisbah 1:3 untuk kedua-dua campuran $C$. furcata/air dan C. furcata/inokulum dengan peratusan penghasilan masing - masing meningkat kepada 1.1 dan 11.9\%. Selain itu, keputusan juga menunjukkan penghasilan semakin meningkat apabila masa tahanan meningkat. Oleh itu, $C$. furcata mempunyai potensi yang bagus sebagai substrat dalam penghasilan biogas untuk tenaga yang boleh diperbaharui pada masa depan. 


\section{Siti Afifah et al: PRODUCTION OF BIOGAS THROUGH ANAEROBIC DIGESTION OF Cabomba furcata IN DIGESTER BATCH SYSTEM}

Kata kunci: Cabomba furcata, penghasilan metana, penghadaman anaerobik, tenaga yang boleh diperbaharui

\section{Introduction}

Biogas is one of the clean renewable energy where the source is easily controlled such as organic waste. Biogas is produced from decomposition of organic material by microorganisms in absence of oxygen. Besides that, biogas also can be produced by anaerobic digestion or fermentation of biodegradable materials such as biomass, fertilizer, municipal waste, crop, crop residue and other plants. Biogas consist of methane, carbon dioxide, nitrogen, hydrogen, hydrogen sulfide and oxygen. In Malaysia, the source for biogas generation such as agriculture waste, animal manure, domestic waste, crops, household waste and others are widely available. Using these materials as biogas sources can provides a number of advantages such as reduce the utilization of fossil fuel, increase farmers income and provide employment opportunities. In addition, biogas production has a great potential to produce neutral carbon dioxide that can prevent the occurrences of emission of greenhouse gases into the atmosphere and simultaneously reduce air pollution as well.

Anaerobic digestion is one of widely used process and attractive method for converting organic waste into for biogas as alternative energy sources [1]. Anaerobic digestion is a natural process in which bacteria decompose the carbon in organic matter. The digestion occurs in three process steps which are hydrolysis, acidogenesis and methanogenesis. In hydrolysis stage, complex organic compounds are broken down by hydrolytic bacteria. Subsequently, in the acidogenesis stage, compounds are further broken into simple molecules by acid-forming bacteria. Then, in methanogenesis stage, methanogenic bacteria will convert the acids into methane gas and carbon dioxide. These processes occur without the presence of oxygen [2]. A few studies have been conducted on biogas production using aquatic plants by applying anaerobic digestion process such as water hyacinth [3], Eichhornia azurea, Pistia stratiotes and Salvini [4], and water hyacinth and water chest nut [5].

Cabomba furcata is a fully submerged aquatic plant that grows readily in Chini Lake, Pahang. Unfortunately, $C$. furcata gives negative impact towards ecosystem in Chini Lake. Recent research indicates C. furcata adversely affects water quality by imparting colour and taint. Cabomba thickets interfere with swimming, boating and fishing, increased the habitat of disease carriers like mosquitoes and reduce habitat available other native plants, fish and others species [6]. Recommendations to utilize an aquatic plant as a renewable feedstock is a good solution for controlling overgrowth of $C$. furcata, save the ecosystem and cost effective. Therefore, this study was conducted to evaluate the potential of $C$. furcata as a substrate for biogas production in a batch digester. The effect of substrate/water ratio and substrate/inoculums ratio were also investigated extensively.

\section{Substrate and inoculums}

\section{Materials and Methods}

C. furcata plant was used as a substrate for biogas production. The plant was collected from Chini Lake, Pahang while inoculums of activated sludge was obtained from sewage treatment plant located in Putrajaya.

\section{C. furcata preparation}

The raw sample of $C$. furcata was weighted and transferred into six different $2000 \mathrm{~mL}$ conical flasks, as batch digesters for carrying out the anaerobic digestion process. Each conical flask contained $500 \mathrm{~g}$ of $C$. furcata substrate at different ratio of sample mixture. Conical flask 1, 2 and 3 were filled with 500, 1000 and $1500 \mathrm{~g}$ of water for 1:1, $1: 2$ and 1:3 of C. furcata/water ratio respectively. Meanwhile, conical flask labelled with 4, 5 and 6 contained 500, 1000 and $1500 \mathrm{~g}$ of inoculums for 1:1, 1:2, 1:3 of $C$. furcata/inoculums ratio respectively as shown in Table 1.

\section{Setup of anaerobic digester}

Anaerobic digester system was setup using $2000 \mathrm{~mL}$ conical flask and $1000 \mathrm{~mL}$ cylinder that filled with water was upturned to trap gas produced during experiment. Both unit was connected using silicon tube as depicted in Figure 1. Each reactor consists of different sample mixture as stated in Table 1. Laboratory anaerobic digester system was developed as shown in Figure 1. 
Table 1. Sample preparation method

\begin{tabular}{llc}
\hline Digester & Sample Mixture & Mixture Ratio \\
\hline 1 & $500 \mathrm{~g}$ C. furcata $+500 \mathrm{~g}$ water & $1: 1$ \\
2 & $500 \mathrm{~g}$ C. furcata $+1000 \mathrm{~g}$ water & $1: 2$ \\
3 & $500 \mathrm{~g}$ C. furcata $+1500 \mathrm{~g}$ water & $1: 3$ \\
4 & $500 \mathrm{~g}$ C. furcata $+500 \mathrm{~g}$ inoculums & $1: 1$ \\
5 & $500 \mathrm{~g}$ C. furcata $+1000 \mathrm{~g}$ inoculums & $1: 2$ \\
6 & $500 \mathrm{~g}$ C. furcata $+1500 \mathrm{~g}$ inoculums & $1: 3$ \\
\hline
\end{tabular}

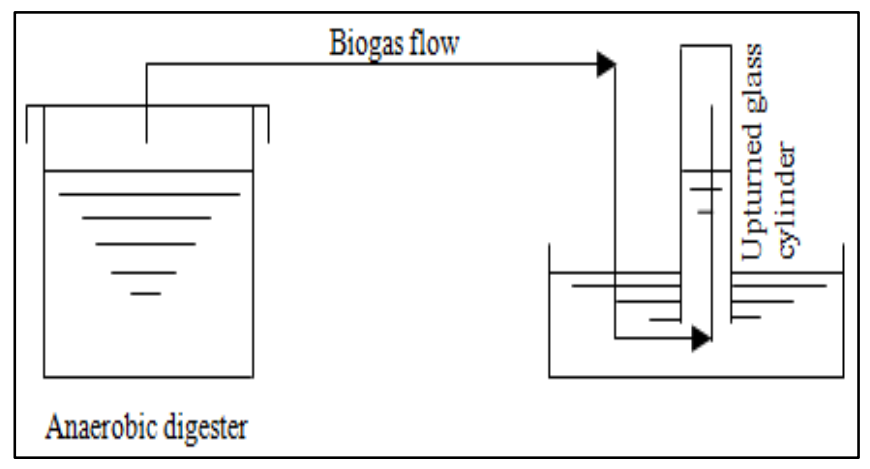

Figure 1. Schematic diagram for anaerobic digester system

\section{Effect of $\boldsymbol{C}$. furcata/water ratios}

\section{Results and Discussion}

As can be seen in Figure 2, a graph of percentage of biogas production versus time was plotted for the sample mixture of $C$. furcata and water for once in week until 28 days. Cumulative biogas production for sample mixture of 1:1 and 1:2 C. furcata/water ratio increased according to time but for ratio of 1:3 C.furcata/water the biogas production increased after day 22 onwards. For sample mixture of 1:1 and 1:2 C. furcata/water there were no $\mathrm{CH}_{4}$ detected during 28 days. Meanwhile for sample mixture of 1:3 C. furcata/water ratio produced $1.1 \% \mathrm{of} \mathrm{CH}_{4}$ started on day 22. At ratio of $1: 1$ of $C$. furcata/water only $3.6 \%, 4.4 \%, 2.1 \%$ and $1.4 \% \mathrm{CO}_{2}$ were produced on day $7,14,21$ and 28 , respectively and only $61.3 \%$ hydrogen was detected on day 28 . The sample mixture of $1: 2$ C. furcata/water ratio produced $0.95 \%$ of $\mathrm{CO}_{2}$ and $50.9 \%$ of $\mathrm{H}_{2}$ on day 7 . Biogas composition majorly consists of methane and carbon dioxide. Meanwhile, nitrogen, hydrogen, hydrogen sulphide and oxygen are minority gases produced during digestion process [7]. Others gases produced during this study might consist of nitrogen, oxygen and hydrogen sulphide. Based on the results, only sample mixture of $1: 3$ C. furcata/water produced $1.1 \% \mathrm{CH}_{4}$. The methane produced from the digestion process could be initiated from native microbes that naturally attached to the $C$. furcata. On top of that, sample mixture of 1:3 C. furcata/water has higher fluid properties compared to others. According to Sara and Veronica [7], fluid properties is an important parameter for feedstock to facilitate the methane bacteria to contact with feedstock and makes the digestion faster. 


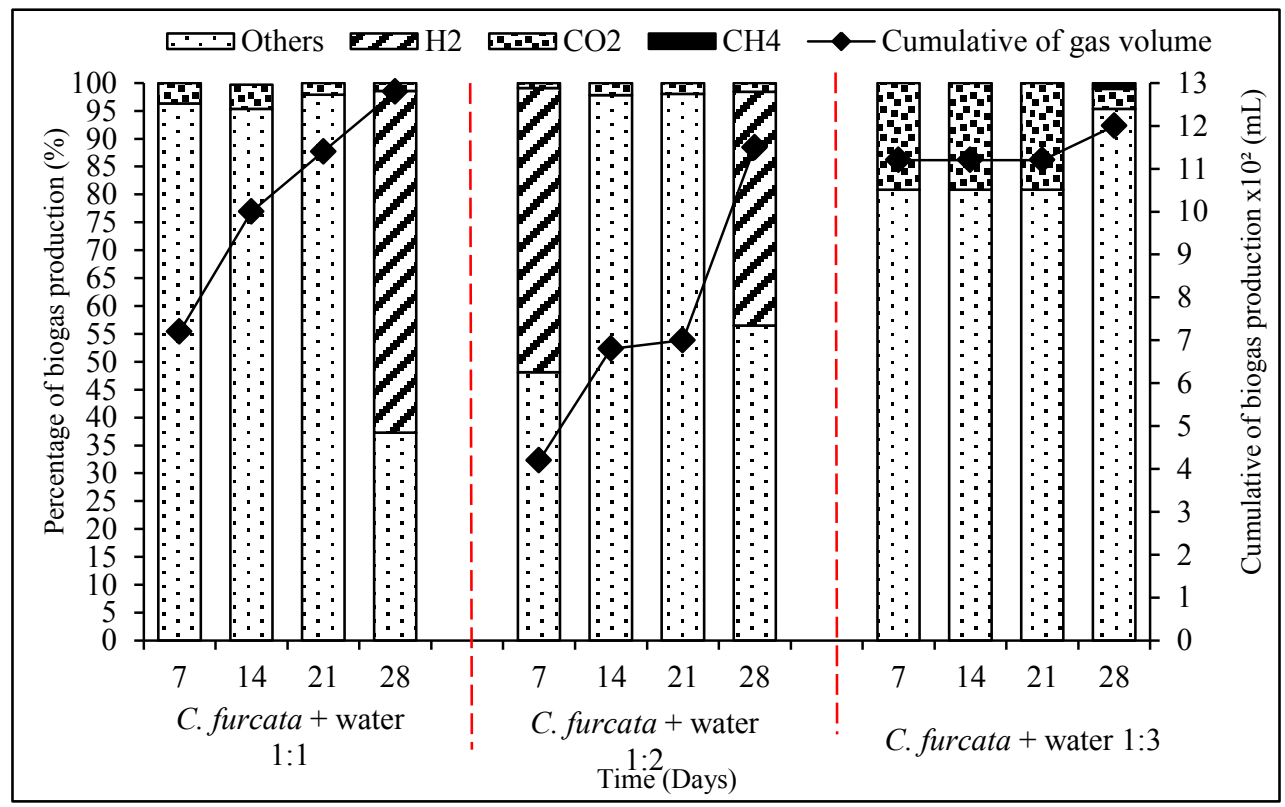

Figure 2. Biogas production from C. furcata/water slurry at different ratio

\section{Effect of $C$. furcata/inoculums ratios}

In Figure 3, the cumulative biogas production for sample mixture of $C$. furcata/inoculums ratio $(1: 1,1: 2$, and 1:3) increased according to time. For sample mixture of 1:1 C. furcata/inoculums ratio, no $\mathrm{CH}_{4}$ detected. Otherwise, $\mathrm{CO}_{2}$ detected on days $7,14,21$ and 28 as $1.3 \%, 2.7 \%, 2.6 \%$ and $2.7 \%$ respectively while $49.3 \%$ of hydrogen produced on day 7 . However, for sample mixture of 1:2 C. furcata/inoculums ratio, about $2.1 \%$ of methane detected within days 22 to 28 followed by $\mathrm{CO}_{2}$ produced on days 7, 14, 21 and 28 as $1.2 \%, 8.2 \%, 3.5 \%$ and $7.3 \%$ respectively. But $\mathrm{H}_{2}$ only produced on day 7 about $85.1 \%$. The percentage of $\mathrm{CH}_{4}$ yield increase can be seen for sample mixture of $1: 3$ C. furcata/inoculums ratio up to $11.9 \%$ during 28 days. While, $\mathrm{CO}_{2}$ production increase day by day as $2.2 \%, 5.5 \%, 3.1 \%$ and $8.5 \%$ on day $7,14,21$, and 28 respectively. $\mathrm{H}_{2}$ only detected on 7,14 and 28 as much as $58.7 \%, 37.0$ and $49.4 \%$ respectively. Based on the previous research, Neo et al. [8] reported that wheat straw produced highest percentage of biogas production up to $59 \%$ when inoculated with cattle manure. Other than that, Sunorso et al. [9] proved that substrates (manure) and inoculums (rumen fluid) exhibit higher cumulative biogas production. Besides, Abu Darieh et al. [10] reported that, methane yield produced from grass mixed with inoculums up to $80 \%$. As a result, inoculums is one of the most important factor affecting the biogas production. In order to produce high $\mathrm{CH}_{4}$ content, inoculums that contain high microbial loading needs to be added in the mixture of biomass to initiate the biochemical processes from anaerobic digester [11]. During this digestion, $\mathrm{CO}_{2}$ produced is less than $10 \%$ for the sample mixture of 1:1 C. furcata/inoculums ratio and 1:2 C. furcata/inoculums ratio compared to $\mathrm{H}_{2}$ produced up to $85 \%$ for 1:3 C. furcata/inoculums ratio. $\mathrm{H}_{2}$ and $\mathrm{CO}_{2}$ are the two other products converted by acidifying bacteria during acidogenesis stage. Khanal et al. [12] reported that optimum $\mathrm{pH}$ for hydrogen produced is at $\mathrm{pH} 5$. Content of liquid in the digester is the main factor in producing of $\mathrm{CO}_{2}$. Reducing in $\mathrm{CO}_{2}$ level in gas phase resulted from higher liquid content in digester and elevated the concentration $\mathrm{CO}_{2}$ dissolved in water [13]. 


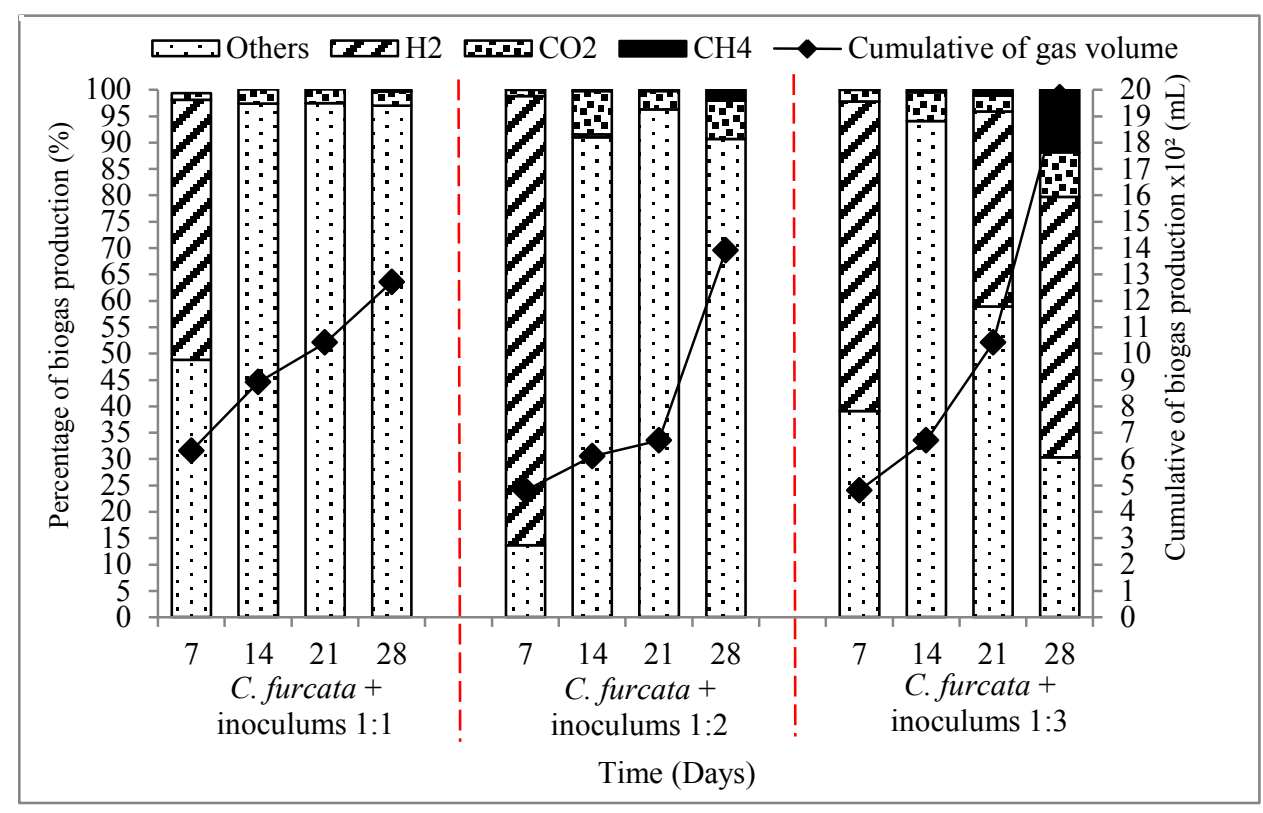

Figure 3. Biogas production from C. furcata/inoculums slurry at different ratios

\section{Variation of $\mathrm{pH}$ and temperature during $\mathrm{CH}_{4}$ production}

During digestion occurred, the variation $\mathrm{pH}$ value was monitored and plotted in Figure 4. $\mathrm{pH}$ value and temperature were monitored regularly at every 3 days and continued until 35 days. The profile of the $\mathrm{pH}$ and temperature for both types of sample mixture were similar. The $\mathrm{pH}$ value dropped from an initial reading of around $\mathrm{pH} 5.5-6.9$ for all samples. The decline of $\mathrm{pH}$ reading from 4.5 to 5 for each sample causes acidic conditions that lead to the failure of methanogenic activity because it inhibits of microbial growth. This occurs when the $\mathrm{pH}$ value drops below 6.5 [14]. Based on these factors, the sample mixture of 1:3 C. furcata/water ratio managed to produce little $\mathrm{CH}_{4}$ on the 28 th day since the final of $\mathrm{pH}$ value in the range of $5-6.2$ because the $\mathrm{pH}$ is less acidic. Similarly, sample mixture of 1:3 C. furcata/inoculums, which resulted in the highest percentage of $\mathrm{CH}_{4}$ as final $\mathrm{pH}$ value of the sample was approaching $\mathrm{pH} 6.5$ that suitable for bacteria involved in anaerobic digestion. During the digestion process, protein degradation might occur and result in increasing ammonia presence that contributed to the elevated $\mathrm{pH}$ during day 17 for all sample mixtures and had inhibited the process [15]. The $\mathrm{pH}$ value decreased on day 20 due to the utilization of ammonia by microbes as nitrogen source for growth. As a result, $\mathrm{pH}$ decreased below than 6.5 , and the conversion of mainly $\mathrm{H}_{2}$ or $\mathrm{CO}_{2}$ to methane and, acetate acid to methane and carbon dioxide by methanogenic bacteria could be reduced during methanogenesis process [16].

As shown in to Figure 5, the temperature for all the samples in the range of $25-30^{\circ} \mathrm{C}$ during the digestion. Ozmen and Aslanzadeh [17] reported that the possible temperature for anaerobic digestion from 3 to $70{ }^{\circ} \mathrm{C}$ and for mesophilic conditions in the range of $20-40{ }^{\circ} \mathrm{C}$. It means that the process of digestion occurred within the mesophilic range. The temperature control of the process is important to ensure the optimum temperature range for the bacteria during methanogenic activity. Based on Figure 2 and Figure 3, the highest percentage of $\mathrm{CH}_{4}$ produced in mesophilic condition up to $11.9 \%$. However, according to Tchobanogous et al. [18], this digestion temperature in this study considered as optimal temperature for the support of biological-reaction rate. 


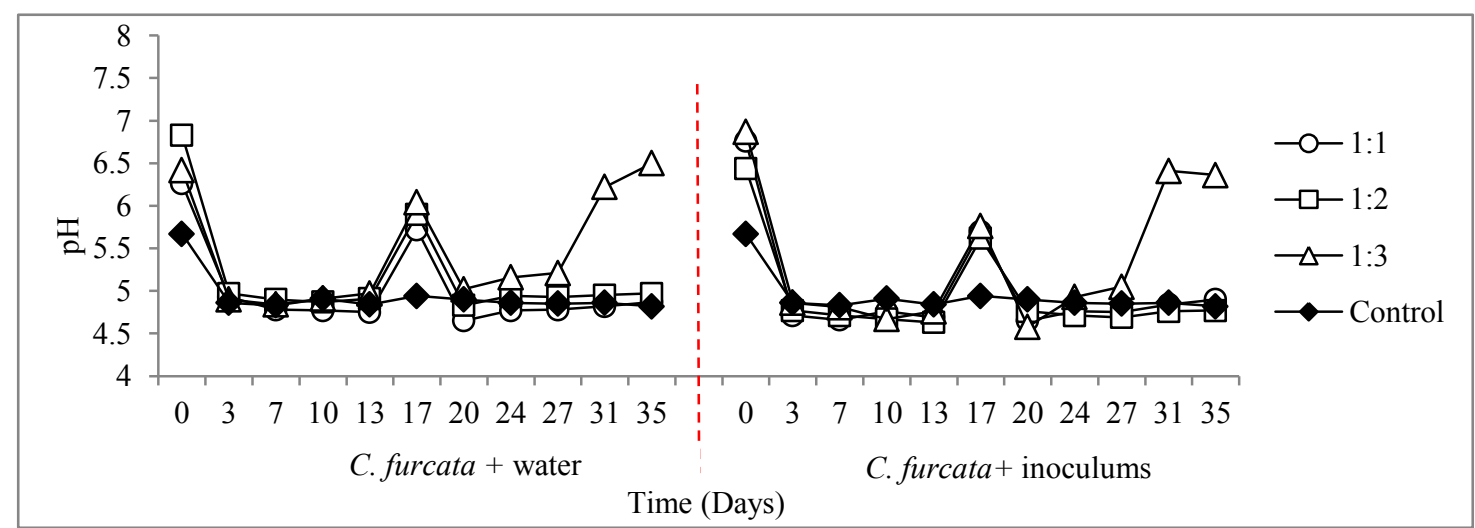

Figure 4. Comparative of $\mathrm{pH}$ value in anaerobic digestion process

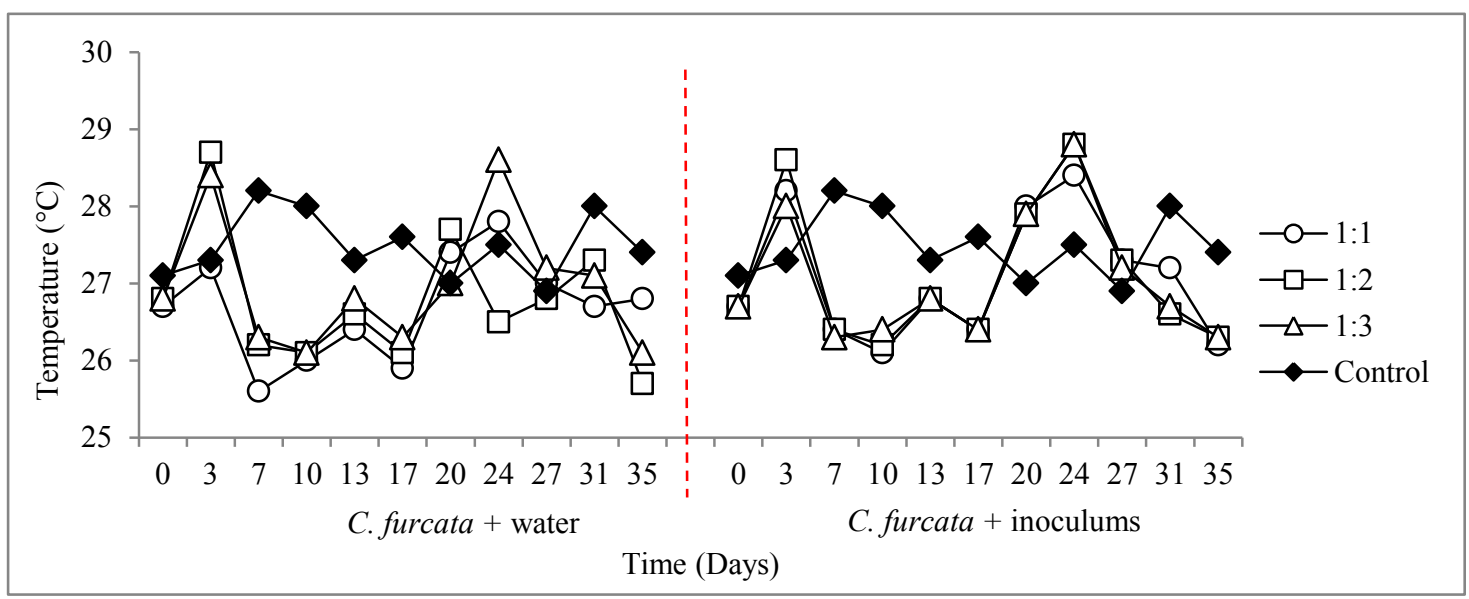

Figure 5. Comparative of temperature in anaerobic digestion process

A sample mixture of $C$. furcata/inoculums shows the percentage increase in $\mathrm{CH}_{4}$ quite significantly up to $11.9 \%$ for sample mixture of 1:3 C. furcata/inoculums ratio as shown in Figure 3. This is because this sample contained of highest soluble/degradable organic load for methanogens. Verma et al. [5] reported that the role of the inoculums, supplying microbial culture and a slurry substrate to begin the process methanogenisis assume equals importance in biogas production. Besides that, the retention time which the period spent by the feed or substrate inside the digester has a significant effect on methane production. The appropriate retention time for mesophilic bacteria is around 20 days. If the retention time is in the short period, the concentration of methane in the formed biogas is less than $50 \%$ and it is not longer combustible [7]. This was proven by the highest amount of biogas produced which started from days 22 for sample mixture of 1:3 C. furcata/water ratio and 1:3 C. furcata/inoculums ratio.

\section{Conclusion}

The result revealed that $C$. furcata has a great potential for utilization as substrate in biogas production. In mesophilic phase, the cumulated biogas volume increased with respect to substrate/water ratio and substrate/inoculums ratio. The most important finding in this research is that the sample mixture ratio of the substrate significantly affect the biogas production. The sample mixture of $C$. furcata/inoculums produced up to $11.9 \%$ of $\mathrm{CH}_{4}$ during 28 days of anaerobic digestion process compared to sample mixture of $C$. furcata/water ratio only produced about $1.1 \%$ of $\mathrm{CH}_{4}$. Besides that, activated sewage sludge can be used as inoculums for anaerobic digestion since it has important roles for start-up of the biochemical processes from anaerobic digesters. 


\section{Acknowledgement}

This research was financially supported by the Ministry of Education (MOE) through Grant No. ERGS/1/2013/TK05/UKM/02/2 and Universiti Kebangsaan Malaysia with Grant No. GGPM-2013-075.

\section{References}

1. Gelegenis, J., Georgakakis, D., Angelidaki, I., Christopouolou, N. and Goumenaki, M. (2007). Optimization of biogas production from olive-oil mill wastewater, by co-digesting with diluted poultry manure. Applied Energy, 84: 646 - 663.

2. Teodorita, A. S., Rutz, D., Prassl, H., Kottner, M., Finsterwalder, T., Volk, S. and Janssen, R. (2008). Biogass Handbook.University of Southern Denmark, Denmark.

3. Kunatsa, T. and Mufundirwa, A. (2013). Biogas production from water hyacinth case of Lake Chivero Zimbabwe. International Journal of Recent Technology and Engineering, 2 (2): 138 - 142.

4. Pereira, R. G., Pereira, M. C. D. E., Silva, J. G., Abreu, F. L. B. and Lameira, V. J. (2011). Production and characterization of biogas obtained from biomass of aquatic plants. International Conference on Renewable Energies and Power Quality (ICREPQ'11). Canary Island Convention Centre Spain.

5. Verma, V. K., Singh, Y. P. and Rai, J. P. N. (2007). Biogas production from plant biomass used for phytoremediation of industrial wastes. Bioresource Technology, 98: $1664-1669$.

6. Department of Agriculture, Fisheries and Forestry (2012). Cabomba. The State of Queensland Fact Sheet. Access from https://www.daf.qld.gov.au/_data/assets/pdf_file/0005/72896/IPA-Cabomba-PP30.pdf [10 February 2013].

7. Sara, S. R. and Veronica, M. S. (2009). Biogas production from waste of the shrimp manufacture in Sisimiut. Arctic Technology: pp. $1-48$.

8. Neo, S., Vintila, T. and Bura, M. (2012). Conversion of agriculture wastes to biogas using as inoculums cattle manure and activated sludge. Scientific papers: Animals Sciences and Biotechnologies, 45(1): 328 - 334.

9. Sunarso, Johari, S., Widiasa, I. N. and Budiyono. (2012). The effect of feed to inoculums ratio on biogas production rate from cattle manure using ramen fluids as inoculums. International Journal of Waste Resources, 2(1): $1-4$.

10. Abu-Dahrieh, J. K., Orozco, A., Ahmad, M. and Rooney, D. (2011). The potential for biogas production from grass. Jordan International Energy Conference: pp. $1-8$.

11. Mateescu, C. and Constantinescu, I. (2011). Comparative analysis of inoculums biomass for biogas potential in the anaerobic digestion. U.P.B. Scientific Bulletin: Series B, 73(3): $99-104$.

12. Khanal, S. K., Chen, W. H., Li, L. and Sung, S. (2004). Biological hydrogen production: Effects of pH and intermediate product. International Journal Hydrogen Energy, 29: 1123 - 1131.

13. Deublein D. and Steinhauser, A. (2011). Biogas from waste and renewable resources. An introduction. $2^{\text {nd }}$ Edition, Revised and Expended edited, Wiley-VCH, Weinheim, Germany.

14. Franco, A., Mosquera-Corral, A., Campos, J. L. and Roca, E. (2007). Learning to operate anaerobic bioreactors. Communicating Current Research and Educational Topics and Trends in Applied Microbiology: pp. 618 627.

15. Neves, L., Oliveira, R. and Alves, M. (2003). Influence of inoculum activity on the bio-methanization of a kitchen waste under different waste/inoculum ratios. Process Biochemistry, 39(12): 2019 - 2024.

16. Zimeminski, K. and Frac, M. (2012). Methane fermentation process as anaeorbic aigestion of biomass: transfromations, stages and microorganism. African Journal of Biotechnology, 11(18): $4127-4139$.

17. Ozmen, P. and Aslanzadeh, S. (2009). Biogas production from municipal waste mixed with different portions of orange peel. Synopsis of Master thesis. University of Boras, Sweden.

18. Tchobanoglous, G., Burton, F. L. and Stensel, H. D. (2003). Waste-water engineering: Treatment and reuse. Fourth edition. Tata McGraw-Hill Publishing Company Limited, New Delhi: pp.1819. 